maintenance. Most of the benches, both of the island and wall type, have tops supported by cantilever brackets which fit into specially designed service stands fixed to the walls and floor. Underbench cupboard and drawer units then slide into a position below the bench tops and conceal the service racks. In the research laboratories the tops can be fixed at either standing or sitting height, or can be removed entirely leaving only the stands and associated services. The service racks are formed by a number of metal supports spaced at approximately 3 -ft. centres and connected at bench-level by a 9 -in. wide horizontal teak strip and a 6 -in. deep teak facia. Curved brackets are fixed to the metal strands which support the service pipes, from which outlets are taken at suitable positions. Where a concentration of service is required, plumbing has been simplified by the use of service towers, which results in a clear bench top and a generally neater appearance. In the physical chemistry research laboratories the bench tops and cupboards form movable integral units. All services are available along the walls, with electrical services also available from ceiling outlets. This gives great flexibility in the arrangement of the laboratories.

Bench tops are of Burma teak (Tectona grandis); all other exposed timber and veneers are of West African mahogany. Teak has also been used throughout as flooring in laboratories. Reagent shelves have been covered with white 'Vitrolite' and the working tops of fume cupboards formed from a sheet of armour-plated glass.

The number of students taking courses in chemistry now exceeds 250, including 37 honours students and 26 research students and fellows. These numbers are expected to increase considerably in the next five years, during which period the College is planning to increase the number of students from 1,500 to 3,000 .

The new facilities make possible very substantial expansion of the research programme in Swansea. As it is, the work of the Department covers a wide range of interest. There is a group working with D. A. Long in the field of molecular spectroscopy with special emphasis on Raman studies. Other groups are concerned with the infra-red spectroscopy of amides (H. E. Hallam et al.), the kinetics of nitrosation reactions (G. Stedman et al.) and solid-state chemistry (K. J. Gallagher et al.). The organic chemists are largely concerned with natural products. This work, which is under the general direction of Prof. C. $\mathbf{H}$. Hassall and Dr. R. F. Curtis, involves work on peptides, cardenolides and alkaloids. A major investigation, dealing with the pathways of biosynthesis of complex phenolic compounds, combines techniques of organic chemistry with others drawn from the relatively young field of chemical genetics. There are also investigations in the field of steroid chemistry (G. H. R. Summers et al.) with particular emphasis on reaction mechanisms.

\title{
SCIENCE AND INDUSTRY_THE PROBLEM OF COMMUNICATION
}

A CONFERENCE, organized by the Department of Scientific and Industrial Research and held in Swansea during April 18-19, had as its primary object the critical examination of present-day methods of disseminating scientific and technical knowledge. Both the papers and the lively discussions which followed indicated the growing concern in scientific and industrial circles with the many-sided nature of this problem.

Opening the conference, Lord Brecon, Minister of State for Welsh Affairs, emphasized the relation between the growth of scientific knowledge, the resultant industrial innovation and the growth of industry. His reference to the time-lag between technical advance and industrial use of new techniques and new materials was echoed by several speakers.

Nine papers were briefly presented to enable delegates themselves to participate in the frank and critical appraisal of the problems and solutions as presented. The first paper, by W. S. Robertson, chief executive of the Scottish Council for Develop. ment and Industry, reminded delegates that as the rolume of available information multiplied there was a proportionate increase in the difficulty of condensing and making that information effectively available to those who could use it. The answer to the increasing volume of literature, it was suggested, might lie in the development of mechanized recording and retrieval systems, but Mr. Robertson maintained that there was still nothing quite so effective as personal contact for passing on new ideas and knowhow. He thought that scientific and technical, as well as commercial, people should be encouraged to travel more widely and more frequently, and he con- demned the inhibiting parochial attitude of many firms which restricted the development of this most useful means of exchanging ideas.

Dr. D. J. Urquhart, director of the National Lending Library for Science and Technology, also emphasized personal contact, and likened the seeker after scientific information to the stranger in a vast, growing, changing eity, the maps of which became out of date almost as soon as they were published. The best and almost only way of reaching an objective quickly was to ask other people working in the specified field. Dr. Urquhart stressed the assistance that libraries and information scientists could provide in making these contacts and warned the conference that existing facilities were inadequate. Quoting Wales as an example, he pointed out that there were only two public libraries with a reasonable holding of scientific periodical literature. The educational aspects of the problem were discussed in the paper by Dr. M. R. Hopkins, senior lecturer in physies at Swansea. He criticized the attitude of narrow utilitarianism which leads to a programme of teaching preoccupied with its immediate purpose. He sug. gested that the training of every educated man and woman should include some teaching of the funda. mental principles of scientific thought, and that both scientists and non-scientists should be educated in the basic skills of communication. Speakers from both platform and floor supported this view; it was pointed out that not one university department specializing in documentation studies existed in Britain. A large increase in the British research effort in this field and the allied one of information retrieval was called for. Following Dr. Hopkins several speakers demanded better facilities for 
documentation research and indicated how poorly this field was supported in Britain. Dr. R. M. Lodge, research manager of British Nylon Spinners, Ltd., spoke on the communication network in an industrial organization and indicated the difficulties of presenting technical information at many different levels within the firm.

The mass media of communication-press, radio, television, films, exhibitions and conferences-were each dealt with in turn by acknowledged experts. It was generally accepted that the primary value of radio, television and films was in creating a healthy climate of opinion to encourage scientific and technical development. Dr. T. Margerison, science editor of the Sunday Times, felt that more use could be made of television by the inclusion of news reports of scientific and industrial developments in magazinetype programmes, and the possibility of implanting the germ of an idea in this way should not be overlooked. Mr. P. Cudlipp, editor of the New Scientist, reviewing the function of the general science journal, stressed the value of scientists and technologists keeping themselves broadly informed on a wide range of scientific disciplines. He referred also to the need for scientists themselves to take $\mathrm{a}$ hand in the preparation of material that the layman could understand, and noted the growing number of science correspondents in the popular press-which was a recognition of the public interest in science. A better balance and more careful reporting of science news had been achieved, but there was still room for improvement. Exhibitions and conferences were dealt with by Mr. E. H. Underwood, the director of public relations for the U.K. Atomic Energy Authority, who stressed the importance of defining objectives and the audience aimed at, but once again, however, personal contact was cited as being very often the most valuable result of attending such functions. Mr. E. Anstey, of the British Transport Commission, and president of the Scientific Film Association, spoke on "Films to Illuminate and Persuade", directing attention to the use of film as a tool not only for spreading scientific knowledge but also for the popular understanding of science.

In a paper by Mr. L. W. Stevens-Wilson, head of the Steel Users Section, British Iron and Steel Research Association, attention was directed to the need for closer collaboration between specialist or vertically oriented technical information services and horizontal or regionally based services. The Department of Scientific and Industrial Research was strongly recommended to set up more branch offices, similar to those existing in Cardiff and Edinburgh.

The widely differing views of delegates and the relative value of the different methods of communicating information made it clear that there is no one ideal solution to the problem. It would appear that there is still need to strengthen all existing techniques. There was general agreement that in many sectors of industry the prevailing level of interest in research and development was not very high, and that the outstanding difficulty was not simply to improve the means of transmitting scientific and technical information but to stimulate interest at the receiving end in industry. How this was to be achieved remained largely an open question, but it must involve a strong element of personal contact to make an effective change in the habits of thought and climate of opinion in both industry and science.

E. E. Williams

\section{AN INTERNATIONAL ANDEAN YEAR}

$\mathrm{O}^{\mathrm{s}}$ $\mathrm{N}$ the initiative of Unesco and by invitation of Dr. Angel Establier, head of the Scientific Office in Montevideo of that Organization in Latin America, who has been interested in such a project from its beginning, a meeting was held in Buenos Aires, during April 3-4, to discuss the planning of an International Andean Year. During such a programme, an intensive study would be carried out on the range of mountains known as the Cordillera de los Andes, from Panama to the southern part of the continent. A small number of scientists from different countries interested were present: Dr. H. O'Reilly Sternberg (Brazil); Dr. Guillermo Mann (Chile); Dr. Tobfas Lasser (Venezuela); Dr. Ovidio Suarez (Bolivia); Eng. Eduardo Baglietto, General M. Olascoaga and Drs. F. Bonorino Udaondo, J. Roederer, Angel Cabrera, M. Sadosky, B. A. Houssay and V. Deulofeu, all from Argentina. Dr. A. Hurtado, from Peru, unfortunately could not attend. Dr. A. Establier represented Unesco and his office will be the centre for the various groups in preparing the project.

After an introductory welcome by the vice-dean of the Faculty of Exact and Natural Sciences at Buenos Aires, Dr. M. Sadosky, Dr. Venancio Deulofeu was elected chairman and Dr. Establier acted as advisory secretary. Four sessions were held.

All present agreed in considering that the project to institute an International Andean Year will be of great importance not only because of its width of interest and of the scientific results which are likely to accrue, but also because of the number of scientists involved and the expected international participa. tion from countries outside South America. It was also considered that a project of this magnitude will have a favourable impact on the progress of science and the future scientific development of most of the South American countries.

Discussions dealt with the fields which it would be desirable to cover during the International Andean Year. As a preliminary list it was considered possible and convenient to work on the following subjects: 1, geology ; 2, botany; 3, geophysics ; 4, human biology ; 5, zoology; 6, human ecology; 7, geomorphology including glaciology; 8, physies of high altitudes; 9 , soil sciences; 10, geography; 11, agronomic sciences (in collaboration with the Food and Agriculture Organization); 12, sociology; 13, ethnography (both 12 and 13 in collaboration with institutes of social sciences); 14, archæology; 15, anthropology; 16, economics (in collaboration with the Comision Económica para América Latina).

In each of these fields some subdivisions have already been made and, as an example of the type of work which would be involved, some specific projects were mentioned. For example, it was suggested that in studying the geology of the Andes, it would be desirable to concentrate the efforts in examining the evolution of the Andean range, especially the tectonic 